\title{
A Clinical Study of Serum Vitamin D Levels in Chronic Tonsillitis among Paediatric Age Group
}

\author{
Sudhakar Rao M S, ${ }^{1}$ Deepak Karade ${ }^{1}$
}

\section{Introduction}

\section{$\underline{\text { ABSTRACT }}$}

Infectious diseases of the faucial tonsils are most frequently encountered by Oto-rhino-laryngologists. Vitamin D has got an important role in the production of surface Anti-microbial peptides (AMPs). Overall, the active form of vitamin D plays a vital role in maintaining the immune system of the body. This study aims to evaluate the association of vitamin D deficiency in chronic tonsillitis among paediatric age group.

Materials And Methods

It is a clinical study carried out in the Department of Oto-Rhino-Laryngology and Head and Neck Surgery at a medical college in Ballari, Karnataka, India from January 2018 to January 2019 for the time period of 12 months. Patients were evaluated with the relevant investigations and digital X-ray nasopharynx along with serum Vitamin D level assessment.

Result

A total of 60 children with chronic tonsillitis were enrolled in this study. There were 26(43.3\%) male children and 34(56.7\%) females, ranging in age group from 5 tol 5 years, mean age is 9.82. The common clinical presentation was recurrent episodes of throat pain seen in all the patients (100\%). On serum 25-hydroxyvitamin D assessment, 40(66.7\%) patients were found to have deficiency and 20(33.3\%) patients were having insufficiency. Mean is $17.99 \mathrm{ng} / \mathrm{ml}$ and ranging from 9.13-28.58ng/ml.

Conclusion

The study concludes that, the serum vitamin D levels in chronic tonsillitis among the paediatric age groups is found to be below normal levels and is unrelated to the socio demographic factors.

$\underline{\text { Kevwords }}$

Vitamin D, Tonsillitis.

$\mathrm{F}$ aucial tonsils are the important constituents of the inner Waldeyer's ring and the specialized lymphoid organs of upper respiratory tract. Infectious diseases of these are most frequently encountered by the Oto-rhino-laryngologists. ${ }^{1}$ Chronic tonsillitis is the leading cause of frequent hospital visit during childhood in the form of recurrent sore throat. ${ }^{2}$ Exact cause for chronic tonsillitis has not been identified yet but major contributory factors are incompliance of the patient to treatment, early stoppage of antibiotics, inadequate absorption of antibiotics, antibiotic resistance, bacterial load, bacterial biofilms and immune system deficiencies. ${ }^{3}$ Chronic tonsillitis is the major reason for the tonsillectomies, and this is associated with significant morbidities and very rarely mortality. Alternative treatment for recurrent or chronic tonsillitis is repeated antibiotic course. ${ }^{4}$
The macrophages located in the crypts of faucial tonsils, plays a crucial role in recognizing the airborne antigens. ${ }^{5}$ Antigens are taken up by the epithelial cells in crypts, these are engulfed by the Toll-like receptors (TLR) which are located on the macrophages. ${ }^{6}$ Structurally pathogens are different from the eukaryotes and this is recognised by TLR, in recurrent tonsillitis TLR's shows variability in its expression. ${ }^{7}$ Vitamin D receptor gene and vitamin D hydroxylase are necessary for the synthesis of vitamin $\mathrm{D}$, activation of TLR has been shown to cause increased

1 - Department of Otorhinolaryngology and Head and Neck Surgery, Vijayanagar Institute of Medical Sciences, Ballari, Karnataka

\section{Corresponding author:}

Dr Deepak Karade

email: dkbims@gmail.com 
expression of these. ${ }^{8}$ Recognition of the pathogen, will lead to synthesis of 1,25-dihydroxyvitamin D inside the macrophage using the extracellular 25- hydroxyvitamin D taken by endocytosis. ${ }^{9}$ The VDR gene located on 12q13.1 gene locus encodes Vitamin D receptor (VDR). ${ }^{10}$ VDR gene shows polymorphism and Apa1, Fok1, Taq1 are the frequently studied polymorphisms. ${ }^{11}$ The endogen defensin gene is stimulated by binding endogenously synthesized 1,25-dihydroxyvitamin D to VDR which increases cathelicidin synthesis, it has direct antimicrobial activity on the bacteria and viruses. ${ }^{12}$ While functions of macrophage like chemotaxis, phagocytosis and bactericidal effect are augmented by vitamin D3. ${ }^{12}$ Anti-microbial peptides(AMPs) plays a vital role in the innate immunity, Vitamin D has got important role in production of this surface AMPs. ${ }^{13}$ Overall active form of vitamin D plays a vital role in maintaining the immune system of the body. ${ }^{14}$ This study assessed the vitamin D levels in chronic tonsillitis to find the association between the Vitamin D deficiency and chronic tonsillitis in paediatric age group.

\section{Materials and Methods}

It is a clinical study carried out from January 2018 to January 2019 for the time period of 12 months. Our study sample is 60 and simple random sampling method is used. Children between 5 year to 15 years of age fulfilling the Paradise et al. criteria of chronic tonsillitis and who are not on any vitamin D supplementation were included in the study. Syndromic children or children with chronic systemic disease or those suffering from malnutrition or obesity or any other nutritional problems were excluded from the study. Children were also excluded if their parents refused their children to participate in the study.

\section{Measurement of serum vitamin D level}

In this study serum levels of 25-hydroxyvitamin $\mathrm{D}$ is assessed, as it is accepted as a reference for determination of vitamin $\mathrm{D}$ level in literature due to its long serum half time. As per Endocrine society guidelines, vitamin $\mathrm{D}$ status is categorized as deficiency below $20 \mathrm{ng} / \mathrm{ml}(50 \mathrm{nmol} / \mathrm{L})$, insufficiency $21-29 \mathrm{ng} / \mathrm{ml}$
(52.5-72.5 nmol/L), sufficiency 30-100 ng/ml (75-250 nmol/L) respectively. ${ }^{15}$ Even though this is accepted widely, as most of the world's population is found to have vitamin $\mathrm{D}$ deficiency, extensive efforts are being made to interpret the basis for this criteria. ${ }^{16}$ Friedman and Brodsky tonsillar enlargement grading system was used. ${ }^{17}$

All patient's parents/guardian were informed about the study and written consent was obtained. The study protocol was approved by the institutional ethical committee. Patients were evaluated with all other relevant investigations and digital X-ray nasopharynx along with serum Vitamin D level assessment. The data is subjected for statistical analysis and $\mathrm{P}$ value $<0.05$ considered as significant.

\section{Results}

A total of 60 children with chronic tonsillitis were enrolled in this study, who met the participation criteria. There were 26(43.3\%) males and 34(56.7\%) females, ranging in age group from 5 to 15 years, mean age being 9.82 years. $37(61.7 \%)$ patients from study population are between 5 to 10 years and 23(38.3\%) are between 11 to 15 years. 39(65\%) children were from rural area and $21(35 \%)$ were from urban. (Table I)

The common clinical presentations were recurrent episodes of throat pain seen in $60(100 \%)$, difficulty in swallowing in $36(60 \%)$, pain during swallowing in $26(43.3 \%)$, snoring in $43(71.7 \%)$, mouth breathing in $44(73.3 \%)$, fever in $18(30 \%)$ and coryza in $6(10 \%)$.

On clinical examination, the assessment of tonsillar enlargement was done using Friedman and Brodsky grading scale. Grade 1 was seen in $1(1.7 \%)$, grade 2 in $14(23.3 \%)$, grade 3 in $42(70 \%)$ and grade 4 in 3(5\%) of study population. Neck was examined for lymph node enlargement, in $22(36.7 \%)$ patients no nodes were palpable, in 28(46.7\%) patients bilateral jugulodigastric lymph nodes were enlarged, in $8(13.3 \%)$ left side and in $2(3.3 \%)$ patients right-side lymph nodes were enlarged. (Table II) On radiographic examination of nasopharynx, adenoid enlargement was seen in $48(80 \%)$ patients. (Table III) On serum 25-hydroxyvitamin D assessment $40(66.7 \%)$ patients were found to have vitamin D 
deficiency, 20(33.3\%) patients were having insufficient vitamin $\mathrm{D}$, mean is $17.99 \mathrm{ng} / \mathrm{ml}$, minimum level is 9.13 $\mathrm{ng} / \mathrm{ml}$, maximum is $28.58 \mathrm{ng} / \mathrm{ml}$ and range is 9.13 $28.58 \mathrm{ng} / \mathrm{ml}$.

All 60 patient's vitamin D levels were below normal range as per Endocrine society guidelines. Mean Serum 25 hydroxyvitamin D in females is $17.05 \mathrm{ng} / \mathrm{ml}$ and in males is $19.23 \mathrm{ng} / \mathrm{ml}$. Mean Serum 25 hydroxyvitamin D in 5 to 10 years of patients is $18.60 \mathrm{ng} / \mathrm{ml}$ and in 11 to 15 years of patients is $17.04 \mathrm{ng} / \mathrm{ml}$. On comparison of serum 25 hydroxyvitamin D levels with Sociodemographic factors, in 25(63\%) females and 15(38\%) males had deficiency and 9(45\%) females and 11(55\%) males had insufficiency respectively. Gender and vitamin D levels were independent [P-0.197, $(>0.05)]$. In 22(36.7\%) patients from 5 to 10 years, $18(30 \%)$ patients from 11 to 15 years of age group had deficiency, and $15(75 \%)$ patients from 5 to 10 years, $5(25 \%)$ patients from 11 to 15 years of age group had insufficiency. Age and vitamin D levels were independent [P-0.274, $(>0.05)]$. In $24(60 \%)$ patients of rural and $16(40 \%)$ patients of urban residents had deficiency, and $15(75 \%)$ patients of rural and $5(25 \%)$ patients of urban residents had insufficiency. Serum vitamin D is also not dependant on place of residency i.e., rural or urban background [P$0.251,(>0.05)]$. (Table I)

On comparison of serum 25 hydroxyvitamin D levels with the tonsillar enlargement grade, $1(2.5 \%), 10(25 \%)$, $28(70 \%), 1(2.5 \%)$ of grade's $1,2,3,4$ respectively had deficiency, and $4(20 \%), 14(70 \%), 2(10 \%)$ of grade 2,3,4 respectively had insufficiency. Tonsillar enlargement grade and serum vitamin $\mathrm{D}$ is also not statistically significant [P-0.543, $(>0.05)]$. (Table IV) On comparison of serum 25 hydroxyvitamin D levels with the adenoid hypertrophy, 34(85\%) patients with adenoid hypertrophy, $6(15 \%)$ patients without adenoid hypertrophy had deficiency, $14(70 \%)$ patients with adenoid hypertrophy, $6(30 \%)$ patients without adenoid hypertrophy had insufficiency. Adenoid hypertrophy and serum vitamin D have no correlations [P-0.171, $(>0.05)]$. (Table III) On comparison of serum 25 hydroxyvitamin D levels with the neck lymph nodes enlargement, in 19(47.5\%) patients bilateral level 2, 4(10\%) patients left side level 2, 2(5\%) patients right side level 2 and 15(37.5\%) patients without any neck lymph nodes enlargement had deficiency and $9(45 \%)$ patients bilateral level 2, 4(20\%) patients left side level 2 and $7(35 \%)$ patients without any neck lymph nodes enlargement had insufficiency, neck node enlargement and vit $\mathrm{D}$ levels are also not statistically related [P-0.564, $(>0.05)]$.(Table II) Age and duration of the symptoms has positive correlation, Pearson Correlation $=0.187$. (Table V)

\section{Discussion}

Vitamins are organic chemical compounds which can be synthesized by the body, sometimes it must be provided through dietary supplements. Among fat soluble vitamins, vitamin $\mathrm{D}$ has got unique characteristics in the body. ${ }^{18}$ Vitamin D deficiency is associated with several diseases like autoimmune diseases, cardiovascular diseases, upper respiratory infection. ${ }^{3}$ Vitamin D has got crucial role in maintaining adaptive immunity. ${ }^{4}$ Several studies have shown the association between Vitamin D levels and recurrent tonsillitis, ${ }^{4}$ adenotonsillar hypertrophy, ${ }^{19}$ tonsillopharyngitis, ${ }^{11}$ otitis media with effusion. ${ }^{19}$ Factors which influences the vitamin D levels in children are maternal factors, environmental factors, dietary factors, exposure to sunlight, regional clothing habits. ${ }^{11,20}$

Serum 25 hydroxyvitamin D half-life is 20 days and is the best parameter for evaluation of vitamin D levels. $1,25(\mathrm{OH}) 2$ vitamin $\mathrm{D}$ is active form, whose half-life is 3 to 6 hours, circulating levels are very low as compared to 25 hydroxyvitamin $\mathrm{D}$, so it is not usually preferred for estimation of vitamin D levels. In our study we have estimated the levels of 25 hydroxyvitamin D due to the ease in estimation by enzyme-linked immunosorbent assay (ELISA) method, it gives both information on body storage of vitamin $\mathrm{D}$ as well as biologically active form of vitamin D.

In our study vitamin D levels was assessed using currently categorized vitamin D levels by endocrine society guidelines. ${ }^{16}$ Even though Alladi et al., Asghari et al., Ayidin et al., and the other authors and organisations vary with this levels. ${ }^{12,19,21}$ Endocrine society guidelines for vitamin D levels are most widely accepted one. .,11,15,16 $^{-1}$ Extensive efforts are being made to interpret the basis of 
Table I: Statistical data on sociodemographic factors \& Vit D Levels

\begin{tabular}{|c|c|c|c|c|c|c|c|}
\hline \multirow{2}{*}{\multicolumn{2}{|c|}{$\begin{array}{l}\text { SOCIODEMOGRAPHIC } \\
\text { FACTORS }\end{array}$}} & \multicolumn{2}{|c|}{ TOTAL } & \multicolumn{2}{|c|}{ VIT D LEVELS (NG/ML) } & \multicolumn{2}{|c|}{ CHI SQUARE TEST } \\
\hline & & FREQUENCY & $\begin{array}{c}\text { PERCENT } \\
(\%)\end{array}$ & $\begin{array}{l}\text { DEFICIENCY } \\
(\leq 20)\end{array}$ & $\begin{array}{c}\text { INSUFFICIENCY } \\
(21-29)\end{array}$ & P VALUE & $\begin{array}{l}\text { SIGNIFI- } \\
\text { CANCE }\end{array}$ \\
\hline \multirow{2}{*}{$\begin{array}{l}\text { Age (In } \\
\text { Years) }\end{array}$} & $5-10$ & 37 & 61.7 & 22 & 15 & \multirow{2}{*}{$\begin{array}{c}P<0.274 \\
(>0.05)\end{array}$} & \multirow{2}{*}{$\begin{array}{c}\text { Not } \\
\text { Significant }\end{array}$} \\
\hline & $11-15$ & 23 & 38.3 & 18 & 5 & & \\
\hline \multirow{2}{*}{ Gender } & Male & 26 & 43.3 & 15 & 11 & \multirow{2}{*}{$\begin{array}{r}P<0.197 \\
(>0.05)\end{array}$} & \multirow{2}{*}{$\begin{array}{c}\text { Not } \\
\text { Significant }\end{array}$} \\
\hline & Female & 34 & 56.7 & 25 & 9 & & \\
\hline \multirow{2}{*}{ Place } & Rural & 39 & 65 & 24 & 15 & \multirow{2}{*}{$\begin{array}{r}P<0.251 \\
(>0.05)\end{array}$} & \multirow{2}{*}{$\begin{array}{c}\text { Not } \\
\text { Significant }\end{array}$} \\
\hline & Urban & 21 & 35 & 16 & 5 & & \\
\hline
\end{tabular}

Table II: Statistical analysis of neck lymph node enlargement with serum 25 hydroxyvitamin D levels in chronic tonsillitis patients

\begin{tabular}{|c|c|c|c|c|c|c|}
\hline \multirow{2}{*}{$\begin{array}{l}\text { NECK (LYMPH NODE } \\
\text { ENLARGEMENT) }\end{array}$} & \multirow{2}{*}{ FREQUENCY } & \multirow{2}{*}{$\begin{array}{l}\text { PERCENT } \\
(\%)\end{array}$} & \multicolumn{2}{|c|}{ VIT D LEVELS (NG/ML) } & \multicolumn{2}{|c|}{ CHI SQUARE TEST } \\
\hline & & & $\begin{array}{c}\text { DEFICIENCY } \\
(\leq 20)\end{array}$ & $\begin{array}{l}\text { INSUFFICIENCY } \\
(21-29)\end{array}$ & P VALUE & $\begin{array}{l}\text { SIGNIFI- } \\
\text { CANCE }\end{array}$ \\
\hline No enlargement & 22 & 36.7 & 15 & 7 & \multirow{4}{*}{$\begin{array}{c}P<0.564 \\
(>0.05)\end{array}$} & \multirow{4}{*}{$\begin{array}{c}\text { Not } \\
\text { significant }\end{array}$} \\
\hline Bilateral level 2 & 28 & 46.7 & 19 & 9 & & \\
\hline Left level 2 & 8 & 13.3 & 4 & 4 & & \\
\hline Right level 2 & 2 & 3.3 & 2 & $\mathbf{0}$ & & \\
\hline
\end{tabular}

Table III: Statistical data of adenoid hypertrophy on digital X-ray examination versus serum 25 hydroxyvitamin D levels

\begin{tabular}{|c|c|c|c|c|}
\hline \multirow{2}{*}{$\begin{array}{l}\text { RADIOGRAPHIC EXAMINATION OF } \\
\text { NASOPHARYNX }\end{array}$} & \multicolumn{2}{|c|}{ VIT D LEVELS (NG/ML) } & \multicolumn{2}{|c|}{ CHI SQUARE TEST } \\
\hline & $\begin{array}{l}\text { DEFICIENCY } \\
\quad(\leq 20)\end{array}$ & $\begin{array}{l}\text { INSUFFICIENCY } \\
(21-29)\end{array}$ & P VALUE & SIGNIFICANCE \\
\hline Adenoid Hypertrophy & 34 & 14 & \multirow{2}{*}{$\begin{array}{c}P<0.171 \\
(>0.05)\end{array}$} & \multirow{2}{*}{ Not Significant } \\
\hline No abnormality detected & 6 & 6 & & \\
\hline
\end{tabular}


Table IV: Statistical analysis of serum 25 hydroxyvitamin D levels with the tonsillar enlargement grade

\begin{tabular}{|c|c|c|c|c|c|c|c|}
\hline & & \multicolumn{2}{|c|}{ DEFICIENCY } & \multicolumn{2}{|c|}{ INSUFFICIENCY } & \multirow{2}{*}{$\mathbf{P}$} & \multirow{2}{*}{ INFERENCE } \\
\hline & & FREQUENCY & $\begin{array}{c}\text { PERCENT } \\
(\%)\end{array}$ & FREQUENCY & $\begin{array}{c}\text { PERCENT } \\
(\%)\end{array}$ & & \\
\hline \multirow{5}{*}{$\begin{array}{l}\text { Oropharynx } \\
\text { (Tonsillar } \\
\text { enlargement } \\
\text { grade) }\end{array}$} & 1 & 1 & 2.5 & $\mathbf{0}$ & $\mathbf{0}$ & \multirow{5}{*}{$\begin{array}{c}0.543 \\
(>0.05)\end{array}$} & \multirow{5}{*}{ Not significant } \\
\hline & 2 & 10 & 25 & 4 & 20 & & \\
\hline & 3 & 28 & 70 & 14 & 70 & & \\
\hline & 4 & 1 & 2.5 & 2 & 10 & & \\
\hline & Total & 40 & 100 & 20 & 100 & & \\
\hline
\end{tabular}

this criteria. ${ }^{16}$

A study conducted by Selvarajan et al. to review the vitamin D levels in Indian population concludes that, vitamin D deficiency is prevalent among apparently healthy Indians living in different regions of the country and is not dependent on age, gender, menopausal status, residence of the individuals. ${ }^{16}$

Reference values needs to be interpreted to an appropriate manner and vitamin D deficiency need not to be considered pandemic and unnecessary screening should be evaded and it should be done for high risk individuals, further studies are needed to establish the normal value for serum $25 \mathrm{OH}$ vitamin $\mathrm{D}$ levels in Indian population. ${ }^{16}$

We have studied, the association between serum vitamin D levels and chronic tonsillitis, with the

Table V: Age wise correlation with duration of symptoms and serum vitamin D levels

\begin{tabular}{|c|c|c|c|}
\hline \multicolumn{2}{|c|}{} & $\begin{array}{c}\text { DURATION OF } \\
\text { SYMPTOMS }\end{array}$ & $\begin{array}{c}\text { SERUM } \\
\text { VITAMIN D }\end{array}$ \\
\hline \multirow{4}{*}{$\begin{array}{c}\text { Age } \\
\text { (Years) }\end{array}$} & $\begin{array}{c}\text { Pearson } \\
\text { Correlation }\end{array}$ & $\mathbf{0 . 1 8 7}$ & $\mathbf{- 0 . 2 7 1}$ \\
\cline { 2 - 4 } & $\mathbf{P}$ & $\mathbf{0 . 1 5 4}$ & $\mathbf{0 . 0 3 6}$ \\
\cline { 2 - 4 } & Inference & $\begin{array}{c}\text { Positive } \\
\text { correlation }\end{array}$ & $\begin{array}{c}\text { Negative } \\
\text { correlation }\end{array}$ \\
\hline
\end{tabular}

existing controversy regarding vitamin D levels, in the midst of current scientific criteria we have found out that all the children with chronic tonsillitis have, serum vitamin D below normal levels. $66.7 \%$ are deficient and $33.3 \%$ has got insufficient levels. It is similar to the study conducted by Elbistanlı et al. ${ }^{13}$ There is no relation between the age, gender and site of residence to explain the low levels of vitamin D, which is similar to the study conducted by Albana et al. ${ }^{22}$ and Alladi et al. ${ }^{21}$ which showed no significant relation between socio demographic variables, in another study conducted by Elbistanli et al. ${ }^{13}$, they concluded that young age and low levels of vitamin D increased the incidence of upper respiratory tract infection(URTI).

There is a positive correlation between age and duration of the symptoms which is invariably related to the chronicity of the disease. We didn't find any relationship between tonsillar size, adenoid hypertrophy, neck node enlargement and serum vitamin D levels. In contrary to our study, Reid et al. found that low vitamin D levels were associated with dark skin, high body mass index, large tonsil size. ${ }^{4}$

Now the question is, whether adding supplementation of vitamin $\mathrm{D}$ will reduce the incidence of Chronic tonsillitis? In randomised controlled studies vitamin D supplementation was shown to reduce the incidence of URTI. ${ }^{13}$ On the contrary, Robertson et al. reported that there was no relationship between vitamin $\mathrm{D}$ levels and URTI and they have concluded that vitamin D 
supplementation didn't reduce the incidence of URTI's in the Norwegian population. ${ }^{23}$

An ideal study should encompass vitamin D level measurements at the same seasonal period. ${ }^{24}$ The logic behind measurement of seasonal changes of serum vitamin $\mathrm{D}$ levels is exposure to sunlight in winter season is very less compared to summer seasons. A study conducted by Khan et al. ${ }^{25}$ and Alladi et al. ${ }^{21}$ ) showed that vitamin D deficiency is more common in children who were not exposed to sunlight.

Further studies with large sample size are needed to investigate the relationship between dietary habits, clothing habits, sunlight exposure, use of sunscreen and relationship between the frequency of tonsillitis during seasonal variation.

\section{Conclusion}

In the midst of current scientific criteria of the serum vitamin D levels, with regards to the cut off values to define the deficiency/insufficiency among the paediatric age groups, this study concludes that the serum vitamin D levels in chronic tonsillitis among the paediatric age groups is found to be below normal levels and is unrelated to the socio demographic factors.

\section{Acknowledgement}

We would like to thank Dr. G. Shankar, Professor and Head of the Otorhinolaryngology and Head and Neck Surgery department, Vijayanagar Institute of Medical Sciences, Ballari, Karnataka, India for his constant support and guidance.

\section{References}

1. Somuk BT, Sapmaz E, Soyaliç H, Yamanoğlu M, Mendil D, Arici A, et al. Evaluation of iron and zinc levels in recurrent tonsillitis and tonsillar hypertrophy. Am J Otolaryngol - Head Neck Med Surg [Internet]. 2016;37(2):116-9. Available from: http://dx.doi.org/10.1016/j.amjoto.2015.11.002

2. Paradise JL, Bluestone CD, Colborn DK, Bernard BS, Rockette HE, Kurs-Lasky M. Tonsillectomy and adenotonsillectomy for recurrent throat infection in moderately affected children. Pediatrics. 2002;Jul:110(1 Pt 1):7-15
3. Nseir W, Mograbi J, Abu-Rahmeh Z, Mahamid M, Abu-Elheja $\mathrm{O}$, Shalata A. The association between vitamin D levels and recurrent group A streptococcal tonsillopharyngitis in adults. Int J Infect Dis [Internet]. 2012;16(10):e735-8. Available from: http://dx.doi.org/10.1016/j.ijid.2012.05.1036

4. Reid D, Morton R, Salkeld L, Bartley J. Vitamin D and tonsil disease - Preliminary observations. Int J Pediatr Otorhinolaryngol [Internet]. 2011;75(2):261-4. Available from: http://dx.doi.org/10.1016/j.ijporl.2010.11.012

5. Nave H, Gebert A, Pabst R. Morphology and immunology of the human palatine tonsil. Anat Embryol (Berl). 2001;Nov;204(5):367-73

6. Lange MJ, Lasiter JC, Misfeldt ML. Toll-like receptors in tonsillar epithelial cells. Int J Pediatr Otorhinolaryngol. 2009; 73(4):613-21

7. Mansson A, Adner M, Cardell LO. Toll-like receptors in cellular subsets of human tonsil T cells: Altered expression during recurrent tonsillitis. Respir Res. 2006; 27(7):36

8. Liu PT, Stenger S, Li H, Wenzel L, Tan BH, Krutzik SR, et al. Toll-like receptor triggering of a vitamin D-mediated human antimicrobial response. Science 2006; Mar 24; 311(5768):17703

9. Adams JS, Liu PT, Chun R, Modlin RL, Hewison M. Vitamin D in defense of the human immune response. Ann N Y Acad Sci. 2007; 1117:94-105

10. Uitterlinden AG, Fang Y, Van Meurs JBJ, Van Leeuwen H, Pols HAP. Vitamin D receptor gene polymorphisms in relation to Vitamin D related disease states. J Steroid Biochem Mol Biol. 2004; 89-90(1-5):187-93

11. Yildiz I, Unuvar E, Zeybek U, Toptas B, Cacina C, Toprak $\mathrm{S}$, et al. The role of vitamin $\mathrm{D}$ in children with recurrent Tonsillopharyngitis. Ital J Pediatr. 2012; 38(1):25

12. Aydin S, Aslan I, Yildiz I, Aĝaçhan B, Toptaş B, Toprak S, et al. Vitamin D levels in children with recurrent tonsillitis. Int J Pediatr Otorhinolaryngol. 2011;75(3):364-7

13. Elbistanlı MS, Güneş S, Yegin Y, Çelik M, Koçak HE, Evren C, et al. Relationship Between Serum Vitamin D Levels and Childhood Recurrent Tonsillitis. Otolaryngol - Open J. 2017; 3(1):16-21

14. Canning MO, Grotenhuis K, de Wit H, Ruwholf C, Drexhage HA. 1- $\alpha, 25$-dihydroxyvitamin D3 $(1,25(\mathrm{OH}) 2 \mathrm{D} 3)$ hampers the maturation of fully active immature dendritic cells from monocytes. Eur J Endocrinol. 2001;145(3):351-7

15. Holick MF, Binkley NC, Bischoff-Ferrari HA, Gordon CM, Hanley DA, Heaney RP, et al. Evaluation, treatment, and prevention of vitamin D deficiency: An endocrine society clinical practice guideline. J Clin Endocrinol Metab. 2011; 96(7):1911-30

16. Selvarajan S, Gunaseelan V, Anandabaskar N, Alphienes Stanley Xavier SS et al. Systematic review on Vit D levels in apparently healthy indian population and analysis of its associated factors. Indian $\mathrm{J}$ Endocrinol Metab [Internet]. 
2017;21(5):765-75. Available from: http://www.ijem.in

17. Powell S. Paeditric obstructive sleep apnoea. In: Watkinson John C, Editor. Scott-Brown's Otorhinolaryngology Head \& Neck Surgery. Eighth Ed. CRC; 2018. Vol. 2; p293-309

18. Kazi MY, Aamir K, Rana MN, Farooq MA. Frequency of Vitamin D3Deficiency in Children Presenting With Frequent Sino-Pulmonary Infections. Pakistan Paediatr J. 2013; 37(2):101-5

19. Asghari A, Bagheri Z, Jalessi M, Salem MM et al. Vitamin D levels in children with adenotonsillar hypertrophy and Otitis media with effusion. Iran J Otorhinolaryngol. 2017; 29(1):2933

20. Collak A. Serum vitamin D levels in children with recurrent tonsillopharyngitis. North Clin Istanbul. 2014;1(1):13-8

21. Alladi YR, Gopal J. Vitamin D Deficiency and Relation to
Recurrent Respiratory Tract Infection in children less than 5 years. J Dent Med Sci. 2017; 16(8):88-96

22. Albanna EA, Ali YF, Am R, Moneim EA. Vitamin D and LL-37 in children with pneumonia Correspondence. Egypt J Pediatr Allergy Immunology 2010; 8(2):81-6

23. Robertsen S, Grimnes G, Melbye H. Association between serum 25-hydroxyvitamin D concentration and symptoms of respiratory tract infection in a Norwegian population: The Tromso Study. Public Health Nutr. 2014; 17(4):780-6

24. Nair R, Maseeh A. Vitamin D: the sunshine vitamin. J Pharmacol Pharmacother [Internet] 2012; 3(2):118-26. Available from: http://www.ncbi.nlm.nih.gov/pubmed/22629085

25. Haider N, Nagi AG, Khan KM. Frequency nutritional rickets in children admitted with severe pneumonia. J Pak Med Assoc. 60(9):729-32. 